\title{
E o lphan retirou o véu da noiva e disse sim. Ecletismo e modernismo no edifício Luciano Costa $^{1}$
}

\begin{abstract}
Renata Cabral ${ }^{2}$
RESUMO: São raros os momentos, na história das políticas de preservação do patrimônio no Brasil, em que se vê a dimensão de um conflito - gerado pela atribuição de valores a um bem cultural - alcançar repercussão significativa, mobilizando diversos agentes. $\bigcirc$ caso do edifício Luciano Costa, no Recife, é um exemplo dessa natureza. Neste artigo, procuramos apresentar - a partir da interpretação de uma trama complexa de discursos e ações - a polêmica preservacionista em torno desse edifício, um exemplar arquitetônico singular, por ter simultaneamente duas fachadas, uma eclética e uma modernista. Em grande parte inéditos, os documentos técnico-administrativos da 5ํㅗㄹ Superintendência Regional e do Departamento de Documentação do Iphan, assim como aqueles da Fundação do Patrimônio Histórico e Artístico de Pernambuco (Fundarpe), da Diretoria de Projetos Especiais da Empresa de Urbanização do Recife (URB-Recife) e do Ministério Público de Pernambuco foram as fontes primárias privilegiadas.

PALAVRAS-CHAVE: Iphan. Ecletismo. Arquitetura Moderna. Recife. Bairro do Recife. Patrimônio cultural.

ABSTRACT: They are rare the moments in the history of the politics for the preservation of heritage in Brazil in which one can see the dimension of the conflict surrounding the attribution of value to a cultural good have significant repercussion, mobilising various agents. The case of the building Luciano Costa, in Recife, is an example of this kind. In this article we aim to present - through the interpretation of a complex web of discourses and actions - the preservationist polemic surrounding this building, a singular example of architecture, because it has two façades simultaneously, one Eclectic and one Modern. Largely unpublished, the technico-administrative documents of the $5^{\text {a }}$ Superintendência Regional $15^{\text {th }}$ Regional Superintendency) and of the Departamento de Documentação (Documentation Department) of Iphan, as well as those of the Fundação do Patrimônio Histórico e Artístico de Pernambuco (Foundation for the Historical and Artistic Heritage of Pernambuco), of the Diretoria de Projetos Especiais da Empresa de Urbanização do Recife (Special Projects Directory of the Urbanisation
\end{abstract}

\author{
1. Versão final e ampliada de \\ tema abordado inicialmente \\ no Seminário Docomomo \\ NO-NE, 3., maio 2010, João \\ Pessoa. \\ 2. Arquiteta, doutoranda em \\ Arquitetura e Urbanismo da \\ Eesc-USP. E-mail: <renataca \\ bral@yahoo.com.br>.
}


3. Ver Carlos Alberto Ferreira Martins (1999).

4. Ver Philip L. Goodwin (1943); Henrique E. Mindlin (2000); e Yves Bruand (1999).

5. Cf. Philip L. Goodwin (1943, p. 25).

6. Cf.Henrique E. Mindlin (2000, p.25).

7. Cf.Yves Bruand (1999, p. 33).

8. Ver Carlos Alberto Ferreira Martins (1999).

9. Ver Lauro Cavalcanti (2000).

10. Cf. Maria Cecília Londres Fonseca (1997, p. 128, 218).

11. Cf. José Pessôa (2003, p. 2-3)

12. Ver Silvana Rubino (1996, p.105).
Company of Recife) and of the Ministério Público de Pernambuco (Public Prosecutor of Pernambuco), were the main sources targeted.

KEYWORDS: Iphan. Eclecticism. Modern Architecture. Recife. District of Old Recife. Cultural Heritage.

Revisões críticas da historiografia da arquitetura brasileira ${ }^{3}$ já anotaram como as narrativas construídas por Goodwin, Mindlin e Bruand 4 ajudaram a naturalizar uma história na qual a "boa arquitetura" aqui produzida seria fruto de uma particular capacidade brasileira de adaptar os modelos estrangeiros às condições climáticas, técnicas, materiais e sociais do país. Como decorrência dessa capacidade, teria sido desenhada, ao longo dos séculos, uma trajetória orgânica da produção arquitetônica nacional, que ligaria realizações do período colonial àquelas da Arquitetura Moderna de vertente corbusieriana.

Interrompendo essa coerente linha de continuidade traçada para a modernidade, estaria, sobretudo, a arquitetura eclética. Aquela "doença", da qual a capital federal soubera curar-se em tempo, nas palavras de Goodwin ${ }^{5}$ ou, nas de Mindlin, as "tendências cada vez mais distantes da realidade" de uma arquitetura de "caráter imitativo"6. Enfim, como escreveu Bruand, o ecletismo que refletiria uma época "caracterizada pela falta de originalidade e por um complexo de inferioridade levados ao extremo"7. Resguardadas as diferenças, em termos gerais essa historiografia produzia uma imagem da arquitetura eclética como uma ruptura do elo entre tradição e modernidade.

Em conformidade com essa leitura, apoiada nas formulações de Lucio Costa $^{8}$, à arquitetura eclética também seria destinado um espaço marginal na constituição da memória da nação. Com "modernistas na repartição"9 do órgão de preservação federal, o atual Iphan, essa arquitetura teria sido preterida, em detrimento, sobretudo, de exemplares do barroco colonial, mas também daqueles neoclássicos e art-nouveau e, ainda, daqueles de Arquitetura Moderna ${ }^{10}$.

Não foram poucos os edifícios modernos a receberem um tombamento precoce. Em 1947, a Igreja de São Francisco de Assis (da Pampulha), em Belo Horizonte, foi tombada ainda inconclusa, após cinco anos do início das obras. Na ocasião, estava ameaçada de abandono pelos proprietários. Em 1948, o edifício do Ministério da Educação e Saúde, no Rio de Janeiro, foi também tombado. $\bigcirc$ edifício tinha sido inaugurado poucos anos antes. Em 1957, a Estação de Hidroaviões, no Rio de Janeiro, foi tombada quando tinha apenas 18 anos e encontrava-se ameaçada de destruição pela construção de um viaduto. Em 1965, era tombado, com um terço do projeto executado, o Parque do Flamengo, no Rio de Janeiro. Por pressões de interesse imobiliário, existia o risco de haver alterações nas normas urbanísticas e consequente ocupação do parque por construções indesejadas ${ }^{11}$.

Rubino argumenta que, ao inscrever suas próprias obras e os marcos modernos criados por eles, os "modernistas-preservacionistas" fizeram do tombamento uma instância de autoconsagração e, assim, deixaram de lado obras do mesmo período ou de período imediatamente anterior ${ }^{12}$. 
cuidado preservacionista em relação a obras ecléticas foi, de fato, bem diferente. As conhecidas afirmativas de Lucio Costa registradas em documento em que polemiza com o conselheiro Paulo Santos a respeito do tombamento de nove prédios ecléticos na avenida Rio Branco, no Rio de Janeiro, são indícios claros de como a arquitetura eclética era tratada no âmbito do órgão de preservação federal no início da década de 1970, mesmo com o arquiteto já aposentado. Costa fortalece a narrativa que ajudou a construir de que a arquitetura eclética não pertenceria à "linha de evolução arquitetônica verdadeira" e não poderia, nesse sentido, ser classificada como representante da "tradição autêntica". Nega a ela, ainda, um lugar na História da Arte, afirmando ser essa arquitetura não um período, mas um "hiato" nessa história"13.

Ao final desse processo, quatro prédios foram tombados e inscritos no Livro de Belas Artes. Nesse momento, ao estilo eclético foi permitida uma restrita amostra de qualidade estética. Na década anterior, apenas três edificações ecléticas haviam sido tombadas, mas por seu valor histórico, em um contexto em que se recorria a esse valor para justificar o tombamento de bens considerados desprovidos de qualidade estética ou que sofreram adulterações ${ }^{14}$.

A partir do final da década de 1970, devido à fusão com o Centro Nacional de Referência Cultural (CNRC), teria germinado, no interior do Iphan, uma visão mais historicizada do valor artístico, que permitiria um entendimento de que traços estilísticos do ecletismo - como o ornamento autônomo, a dissimulação de materiais e a alusão a estilos passados - não eram negativos, embora contrários aos cânones da Arquitetura Moderna ${ }^{15}$.

Ocorreu também um movimento de mudança em relação à forma de lidar com os centros históricos. Trata-se de um percurso que teve seu início na década de 1930, seu marco de inflexão no pós-guerra, e seu ápice na década de 1970. Nesse intervalo, uma prática de preservação fundamentada exclusivamente em critérios estilísticos e preocupada em construir uma ideia abrangente de nação mudaria para uma que incluia critérios econômicos e sociais, e que se preocupava em viabilizar políticas urbanas de desenvolvimento ${ }^{16}$. llustrativos dessas duas práticas seriam os tombamentos, respectivamente, de Ouro Preto e do Bairro do Recife.

É no novo contexto de esvaziamento dos vínculos entre a ideia de "nação" e de patrimônio que se situa o primeiro tombamento federal de um conjunto predominantemente eclético, o Bairro do Recife.

E é justamente no Bairro do Recife - tombado e, em parte, "revitalizado" e festejado, onde os vestígios da desvalorização do ecletismo como patrimônio encontravam-se diluídos, em meio às novas cores das edificações - que um imóvel parecia ainda representar, em sua materialidade, todo o atrito histórico advindo da postura modernista para com o ecletismo. $\bigcirc$ edifício Luciano Costa foi construído no bojo da reforma haussmanniana que, na década de 1910, transformou o lugar (Figura 1). Na década de 1960'17, contudo, recebeu uma segunda fachada de caráter modernista (Figura 2), sobreposta àquela original eclética e que, por estar afastada dela, permitiu a coexistência das duas fachadas em um único prédio (Figura 3).
13. O documento, de 1972, está transcrito em José Pessôa (1999).

14. Maria Cecília Londres Fonseca (1997, p. 218, 223).

15. Idem, p. 223.

16. Ver Rogério Proença Leite $(2007$, p. $47-60)$.

17. A conclusão do projeto data de dezembro de 1959 , tendo sido aprovado pela Prefeitura Municipal do Recife em janeiro de 1960; ver Luiz Amorim (1999). 


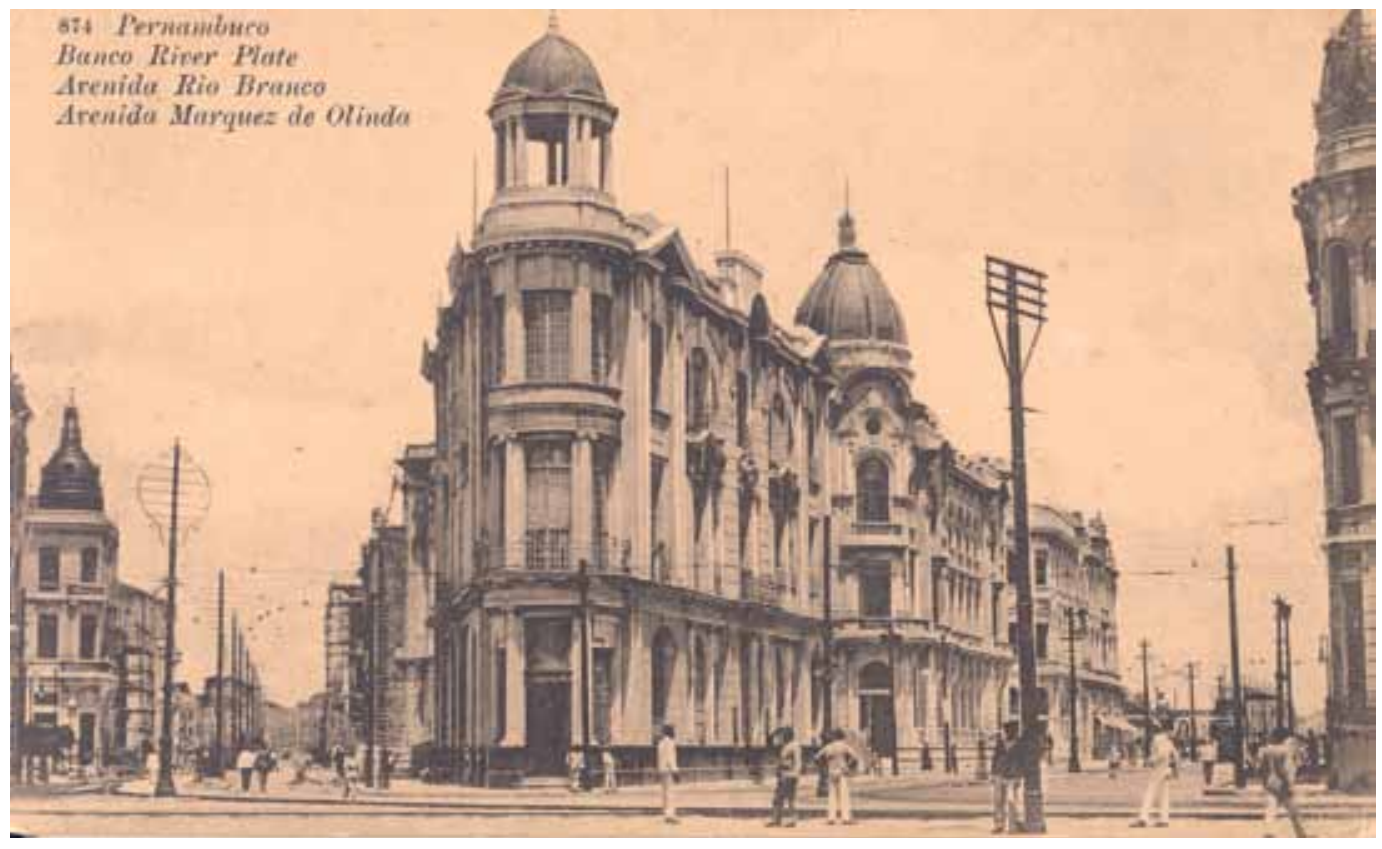

Figura 1 - $\bigcirc$ edifício Luciano Costa aparece em segundo plano, por trás do prédio do Banco River Plate, ambos situados entre as principais avenidas abertas na reforma urbanística da década de 1910. Cartão-postal. Missiva de 1919. Acervo da Fundação Joaquim Nabuco, Recife.

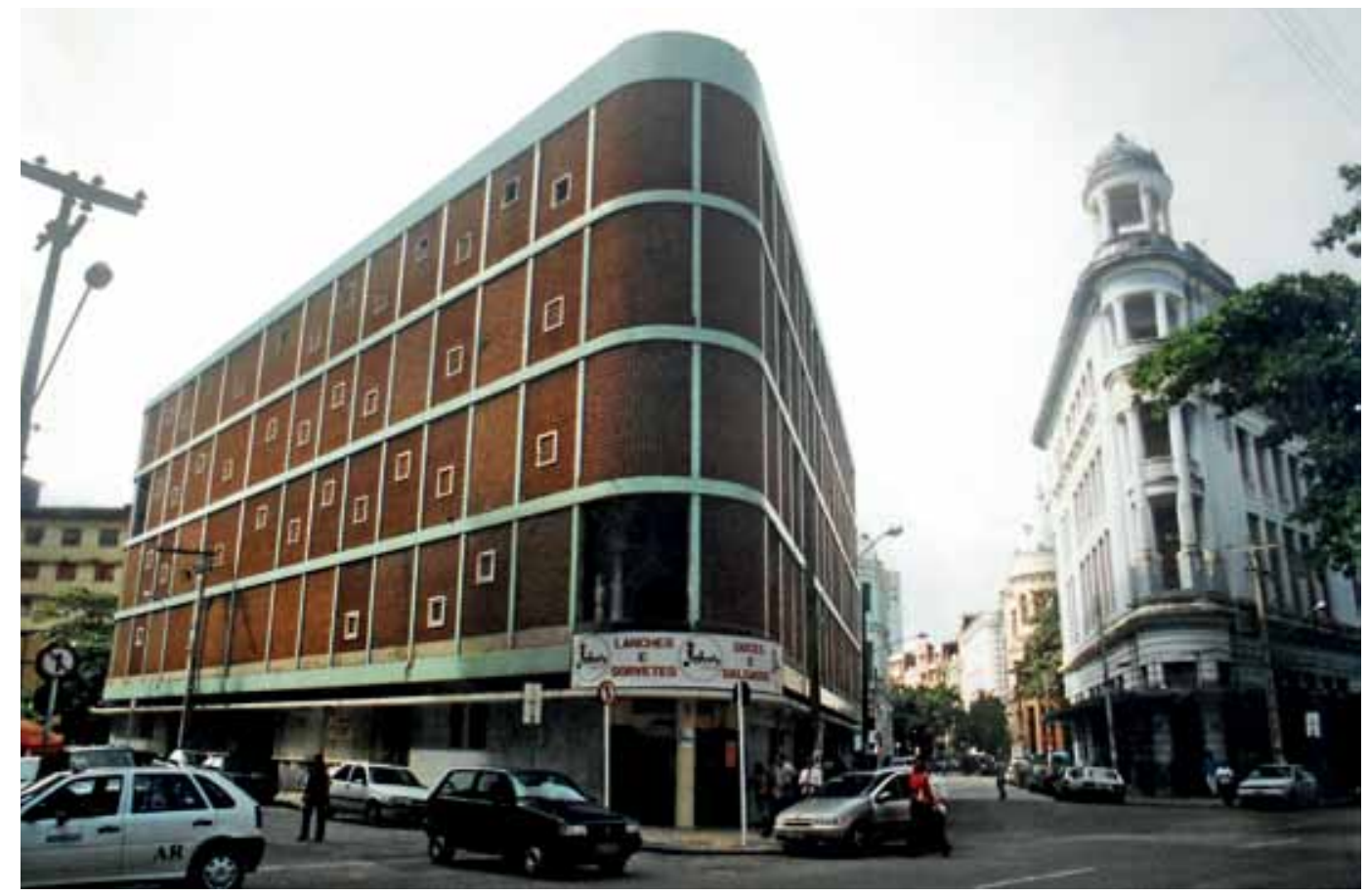

Figura 2 - Edifício Luciano Costa com a fachada de cobogós. Fotografia de 2001 . Parecer de José Aguilera. Acervo 5 SR - Iphan / MinC, Recife. 


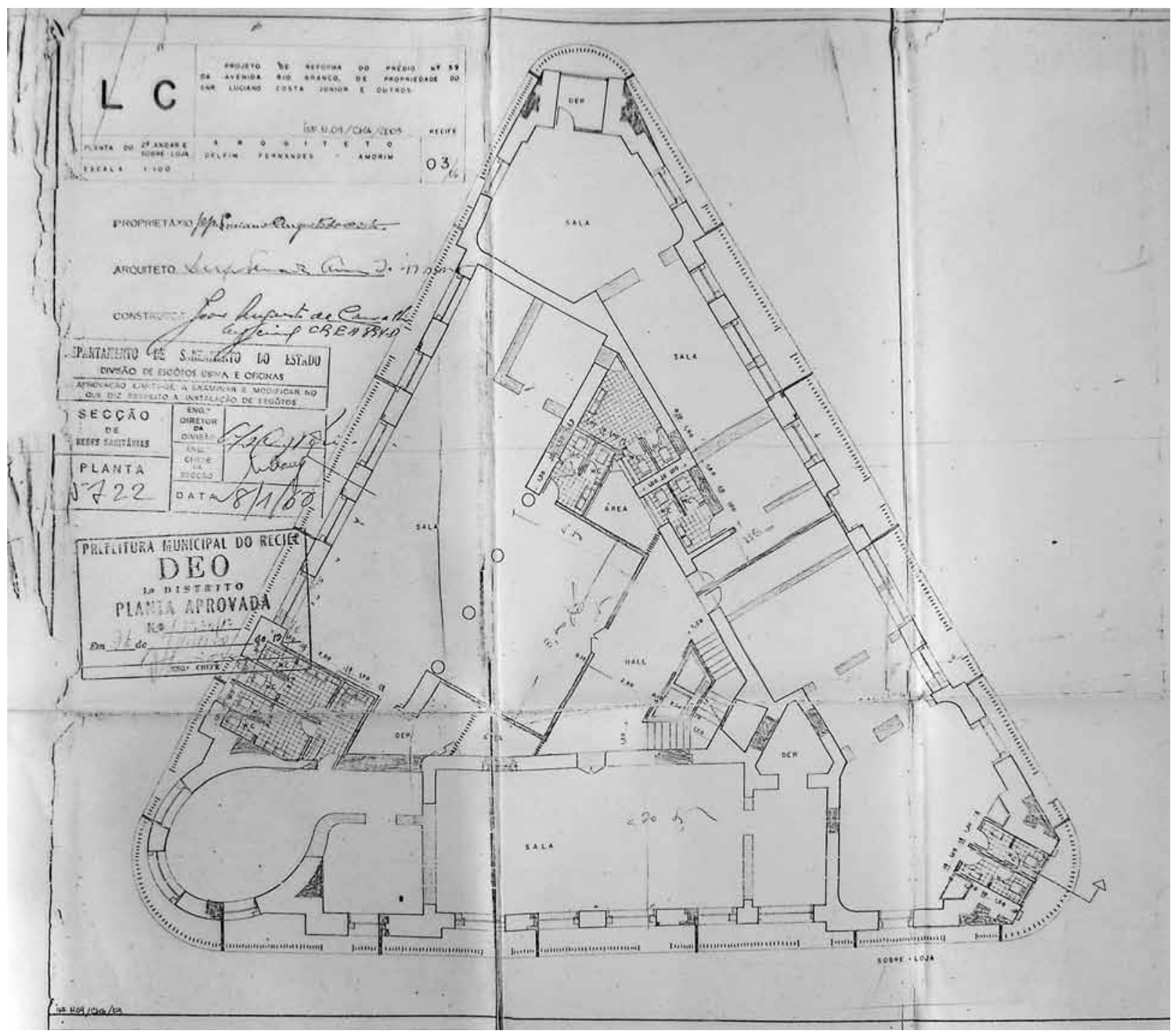

Figura 3 - Planta baixa da sobreloja, segundo proposta de reforma de Delfim Amorim, assinada e com carimbos de aprovação na Prefeitura do Recife e no Departamento de Saneamento do Estado. Observar fachada de cobogós representada por traços paralelos, afastada da alvenaria do edifício. Acervo 5오 SR Iphan / MinC, Recife. 
18. Cf. Philip L. Goodwin (1943, p.87).

19. Cf. Henrique E. Mindlin (2000, p. 33).

20. Cf. Yves Bruand (1999, p. 79).

21. Ver Luiz Amorim (1994); Geraldo Gomes (1994).

22. O Bairro do Recife foi tombado pelo Iphan, Portaria $n$. 263, de 23 jul. 1998 , publicada no Diário Oficial da União em 24 jul. 1998.
A fachada sobreposta era constituída por um pano de cobogó lou combogól, sustentado por uma trama estrutural de vigas e pilares de concreto. $\bigcirc$ cobogó, já citado em Goodwin como "cambogé" 18 , também é mencionado, no texto de Mindlin, como elemento atenuador da "ofuscação" ou tecedor de "rendados de sombra" nas fachadas ${ }^{19}$ e, em Bruand, como a criação mais notável da equipe do arquiteto Luis Nunes, em Pernambuco, que teria transformado algo que servia tradicionalmente para a construção de paredes fechadas em "brise-soleil elementares" que asseguravam uma boa ventilação e proteção adequada contra os "elementos naturais" 20 .

O uso do cobogó representaria, como o dos brise-soleil tão amplamente mencionados desde Goodwin, uma das importantes contribuições brasileiras para a nova arquitetura, símbolo da capacidade de adaptação da Arquitetura Moderna às condições particulares do país e ligação com a tradição já presente nas rótulas coloniais. E marcaria fortemente a iconografia da Arquitetura Moderna no Brasil, sendo capturado como um dos ângulos privilegiados em fotos dos edifícios residenciais Nova Cintra, Bristol e Caledônia, no Parque Guinle, de Lucio Costa; da Escola Primária do Conjunto Residencial de Pedregulho, de Affonso Eduardo Reidy; ou, ainda, da casa de Oswaldo Artur Bratke, do próprio Bratke, e da Caixa d'Água de Olinda, de Luis Nunes.

Além de ser constituída por um material ícone da originalidade da modernidade brasileira, a fachada do edifício Luciano Costa foi, ainda, projetada pelo arquiteto Delfim Amorim, um dos pioneiros, e das mais importantes personagens, na história de consolidação de uma cultura arquitetônica modernista na cidade do Recife.

Visto, por uns, como símbolo da importante reforma urbanística da década de 1910; por outros, como símbolo da Arquitetura Moderna com a assinatura de Delfim Amorim; ou, ainda, como testemunho da relação entre modernismo e ecletismo, esse edifício será alvo, no final da década de 1990, de uma grande polêmica preservacionista, iniciada no momento em que os proprietários solicitam uma autorização institucional para retirar a fachada modernista.

O prédio, que teria recebido a alcunha popular de "véu de noiva" 21, provavelmente em referência ao rendilhado dos cobogós, a encobrir o "rosto" do prédio, perderia seu "véu" modernista em 2006.

Este artigo apresenta cronologicamente os discursos dos diversos agentes envolvidos nessa polêmica, de forma a tornar pública uma documentação primária ainda inédita. Configura-se como uma primeira aproximação a um corpo documental rico, que pode ser lido como parte da história recente do Iphan, a trazer indícios das relações dessa instituição com o ecletismo e o modernismo, e de seus critérios de valoração de bens culturais.

Em 1999, quando o Bairro do Recife já se encontrava tombado22 e a rua do Bom Jesus já mostrava os resultados do plano de "revitalização", com bares e restaurantes ocupando as edificações pintadas pelo Projeto Cores da Cidade (Fundação Roberto Marinho), os proprietários do edifício Luciano Costa, localizado na continuidade dessa rua (Figura 4), percebendo o movimento de valorização 


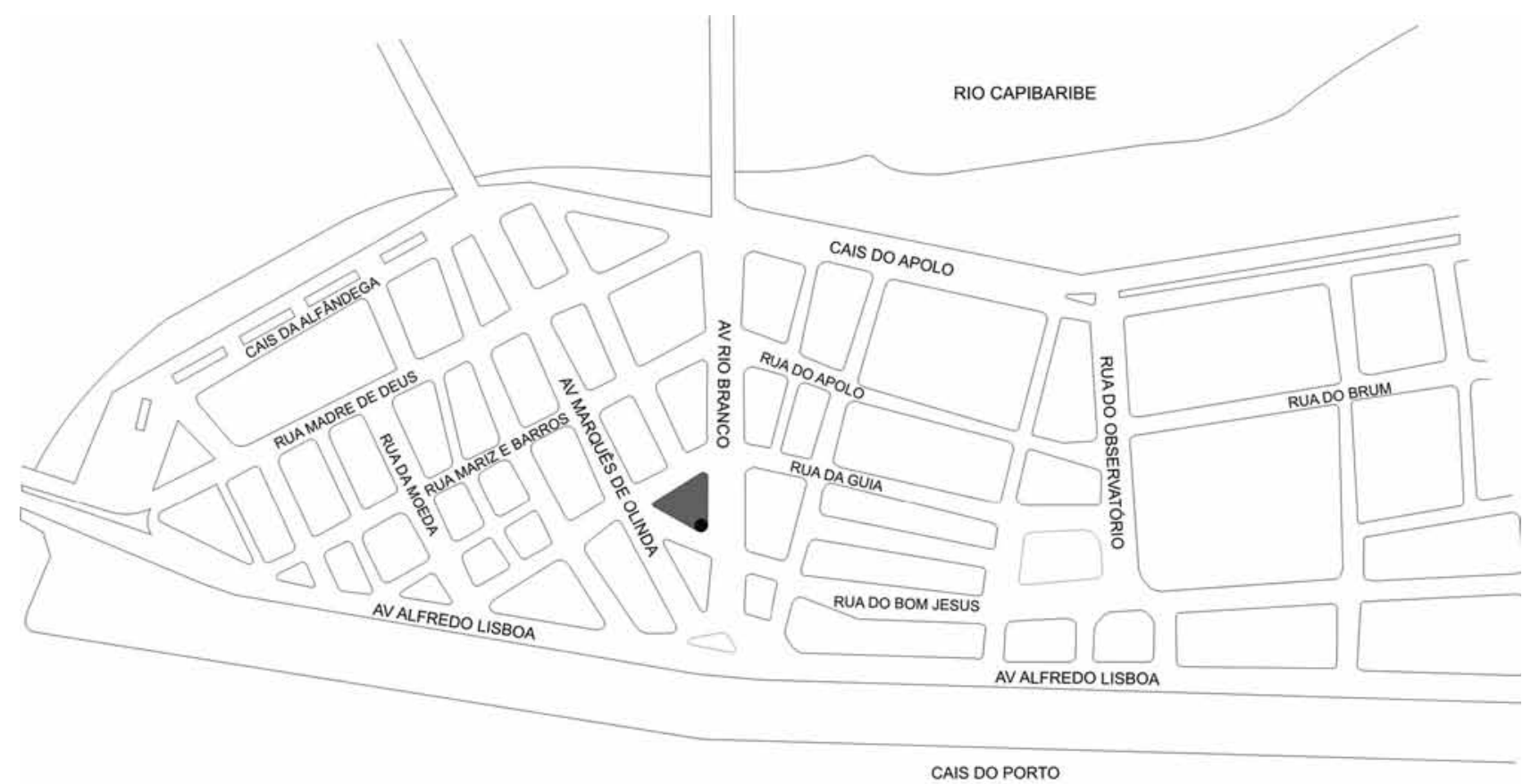

OCEANO ATLÂNTICO

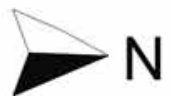

Figura 4 - Mapa com indicação, em cinza, do edifício Luciano Costa. O círculo preto indica a esquina que era coroada por uma cúpula. Ficha Cadastral Q-200. Proposta de Tombamento do Núcleo Original da Cidade do Recife (redesenho). Acervo 5SR-Iphan / MinC, Recife.

do ecletismo e de possibilidades de parcerias com o poder público, solicitam à Diretoria de Projetos Especiais (DPE), da Empresa de Urbanização do Recife (URB-Recife), "apoio técnico e orientação para captação de recursos" para a remoção dos cobogós e "restauração externa da estrutura original do edifício". A falta de intimidade com os termos usuais ao modernismo brasileiro, como cobogó, que eles chamam "combongóes" não se mostra em relação à compreensão do processo de "revitalização" do Bairro. Os proprietários alegam reconhecer
23. Carta de Marta Costa de Rooy, Ida Costa Bezerra de Mello e Eduardo de Oliveira Costa à Diretoria de Programas Especiais (DPE) da Empresa de Urbanização do Recife (URB-Recife), datada de 4 ago. 1999, fl. 1 .

que a estrutura externa com combongóes [sic] proposta e construída nos anos 1950 pelo arquiteto Delfim Amorim, foi oportuna para a época quando o bairro do Recife estava muito depreciado e havia necessidade de modernizar a parte externa do edifício. Não vemos no entanto justificativa estética para perpetuar a solução do arquiteto quando a cidade do Recife se esforça para reencontrar o seu passado através de um bem sucedido programa de restaurações ${ }^{23}$.

Os proprietários situam historicamente a intervenção de Delfim Amorim como modernizadora. A partir da distinção entre dois momentos, meados do 
24. URB-Recife, Ofício 479, de 13 set. 1999. Documento assinado por Rúbia Campêlo de Farias, então diretora de Programas Especiais

25. Cf. Rogério Proença Leite (2007, p. 80).

26. Cf. Noé Sérgio apud Ana Nogueira (1998, p. 52).

27. Governo Municipal, Proposta de Tombamento do Núcleo Original da Cidade do Recife, Ficha Cadastral: Imóveis Destaque ID-14. século XX e a atualidade, inserem-se no seu tempo e no que está acontecendo ao seu redor, querendo compartilhar dessa fatia do bolo, quando Recife "reencontra seu passado". À fachada modernista atribui-se um valor histórico, mas que, para eles, não é um valor que justifique a perpetuação de uma determinada solução arquitetônica para as gerações futuras. Apenas o valor estético justificaria uma atitude conservacionista, mas faltaria à fachada de cobogós tal qualidade necessária.

Além desses aspectos, os proprietários somam, à sua argumentação, questões mais pragmáticas, que dizem respeito ao risco de desabamento da estrutura de sustentação dos cobogós e aos riscos à saúde pública, por ser o espaço entre as duas fachadas um local de permanência de pombos.

Por ser o Bairro do Recife tombado (1998), a questão é encaminhada

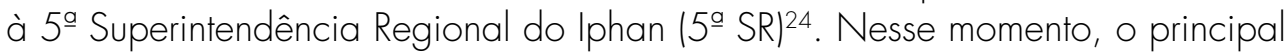
documento a atribuir valor ao edifício era a Ficha Cadastral desse imóvel, incorporada à proposta de tombamento do conjunto, já que o edifício é classificado como "imóvel de destaque".

Os argumentos da Ficha Cadastral do edifício Luciano Costa acompanham aqueles da proposta de tombamento do Bairro. O argumento central dessa proposta para o conjunto urbano era o da heterogeneidade de estilos e traçados nele presentes, que incluía, destacadamente, a reforma de características haussmannianas ocorrida na primeira década do século XX, em meio a vestígios simultâneos de um passado colonial e de intervenções de arquitetura modernista e contemporânea ${ }^{25}$. Na construção de sentidos para o pretendido patrimônio, foram destacados 51 prédios, dentre eles o Luciano Costa, que, segundo palavras de Noé Sérgio, do Escritório Técnico de Revitalização do Bairro do Recife, da Prefeitura do Recife, dariam justamente "uma aula de história do desenvolvimento e da ocupação do bairro"26. Localizado no trecho mais monumental da área da reforma da década de 1910, e ocupando toda uma quadra de forma triangular, a "aula de história" a ser dada pelo edifício era a de ser um exemplar "singular" desse novo Recife de ares parisienses:

Como decorrência da malha urbana aplicada na reforma do bairro do Recife, a quadra onde se encontra o prédio de ํㅡ 170 é de forma triangular. Tal situação deu ao edifício uma característica, por ocupar toda a quadra, muito singular. Uma cúpula de ferro marcava o ângulo voltado para a avenida Rio Branco. Em tempo relativamente recente, anos cinquenta, uma intervenção de responsabilidade do arquiteto Delfim Amorim, no propósito de resguardar a composição eclética, revestiu o exterior do edifício com uma malha de concreto em vigas e pilares que recebeu cobogó de cerâmica. A intervenção salvadora já se integrou à arquitetura do Recife e deve ser preservada ${ }^{27}$.

Nessa narrativa, a intervenção de Delfim Amorim teria tido o propósito de "resguardar a composição eclética" e é chamada de "intervenção salvadora", apesar da improbabilidade ou da excepcionalidade de uma intenção de tal natureza ter partido de um arquiteto moderno. Adquire peso, nessa construção, o edifício eclético, em detrimento da adição modernista. 
Ao final, a sentença dada ao Luciano Costa, com suas duas fachadas, foi a de que a intervenção de Delfim Amorim já teria se "integrado" à arquitetura do Recife e deveria ser preservada.

É com esse antecedente documental que, em setembro de 1999, a 5a Superintendência Regional do Iphan elabora um parecer favorável à retirada dos cobogós ${ }^{28}$. Dialogando com as questões colocadas pelos proprietários, o parecerista, uma arquiteta, atesta, após vistoria no imóvel, que, no espaço entre as duas fachadas, "a higiene deixa a desejar" em função da presença dos pombos. Sobre a segurança da estrutura, aponta que há oxidação na ferragem de sustentação da segunda fachada, que ela chama de "septo", "requerendo esta, a execução de serviços de conservação e manutenção". Antes dessas considerações, anota, provavelmente com base na Ficha Cadastral já referida, que "a fachada original foi intencionalmente preservada na reforma sofrida no início da década de 60" e que se apresenta "praticamente íntegra a partir do primeiro pavimento". Reafirmava-se a reinvenção da fachada modernista como "intencionalmente" preservadora da eclética e inaugurava-se o uso desse argumento de "intencionalidade" como um fortalecedor da defesa pela retirada dos cobogós, ignorando-se que, para teóricos do restauro, como Brandi e outros que o precederam, as intenções originais do criador não têm papel determinante na decisão do conservador, importando o edifício como encontrado.

Mas foi, sobretudo, "considerando o interesse da preservação do Conjunto Tombado pelo Iphan", predominantemente eclético, que o parecerista coloca que "não vemos nada a opor quanto à concessão da autorização solicitada". Aqui parece prevalecer a ideia de homogeneidade estética de agrupamentos urbanos tombados, a partir de uma leitura essencialmente formal do conjunto, que não leva em consideração sua característica documental. Trata-se de uma noção enraizada no Iphan, cuja prática levou, por exemplo, ao controle do aspecto colonial na arquitetura nova, em acréscimos e em reformas em Ouro Preto 29.

Esse parecer é possível (da forma como foi elaborado) porque o imóvel foi destacado no conjunto tombado mais pela importância de sua inserção urbanística na área da reforma da década de 1910 do que pelo fato singular de ter uma fachada modernista sobreposta a uma eclética. Nesse sentido, o parecer respeita os termos anteriores da Ficha Cadastral, embora, diferentemente dela, não oriente a conservação da fachada modernista. Apresenta, contudo, contradição em relação aos argumentos do tombamento do Bairro, raro caso em que o Iphan tombou um conjunto marcadamente heterogêneo. É importante lembrar que, na proposta de tombamento, no mesmo subnúcleo onde se encontra o edifício Luciano Costa, há dois "imóveis de destaque" datados como "pós-50" (Banco do Brasil e Edifício-sede do Bandepe), ambos de linguagem arquitetônica modernista e que não teriam manchado, na narrativa da proposta de tombamento, o "interesse da preservação do Conjunto Tombado", alegado no parecer da 5 a SR. Dito de outra forma, o subnúcleo onde o edifício Luciano Costa se encontrava já não era um conjunto homogêneo quando de seu tombamento, e ele não era o único edifício de aparência modernista. É o entendimento desse parecer que vai
28. Iphan, $5^{\text {a }} \mathrm{SR}$, Informação $n .22 / S K / 99$, de 16 set. 1999. Documento assinado por Silvia Katz, arquiteta da $5^{\text {a SR. }}$

29. Ver Lia Motta (1987). 
30. Iphan, $5^{\mathrm{a}} \mathrm{SR}$, Ofício n.260/99/, $5^{\text {a }}$ SR/Iphan/ MinC, de 23 set. 1999. Documento assinado por Roberto de Hollanda.

31. Cf. Luiz Amorim (1994, p. $230-231 ; 1999$, p. 14).

32. Idem, 1994, p. 223; 1999, p. 9.

33. Cf. Geraldo Gomes (1994, p. 78). fundamentar o consentimento do então superintendente da $5^{a}$ SR para a restauração da fachada eclética ${ }^{30}$.

De forma resumida, o parecer da 5⿳⺈ SR privilegiava o argumento da intencionalidade do arquiteto modernista em preservar a fachada eclética, numa visão historicamente não fundamentada, e pautava-se no entendimento de que a harmonia formal entre os edifícios do conjunto urbano deveria ser mantida.

Três meses depois, em dezembro de 1999, Luiz Amorim, arquiteto, professor da Universidade Federal de Pernambuco e filho de Delfim Amorim, apresenta um trabalho no congresso de arquitetura III Seminário DOCOMOMO Brasil. O texto é uma versão ampliada e atualizada de um artigo publicado por ele em 1994.

Apresentando diretrizes para uma possível ação no edifício, os dois trabalhos, de 1994 e 1999, apresentam o entendimento de que o edifício é um "híbrido", "que não se constitui de um edifício deturpado por uma reforma, nem uma reforma que lamenta o suporte que tem" ${ }^{\prime 31}$. Híbrido, sobretudo, porque nele o projetista deixou latente "dois tipos de espaços: o eclético transformado e o moderno idealizado" 32 .

Ambos os artigos dedicam espaço para investigar os princípios que nortearam a intervenção de Delfim Amorim. Sobre a fachada, anotam - a partir da comparação entre um estudo preliminar, o projeto apresentado para aprovação na Prefeitura e a obra - uma mudança: de uma atitude de "substituição" se teria passado a uma de "sobreposição" ou "apositiva", já que, primeiramente, o arquiteto tinha proposto uma fachada substituindo, materialmente, a eclética. No artigo de 1994, a interpretação desse dado aparece como uma "atitude de preservar", enquanto no de 1999 aparece como uma "presumível atitude de preservar". O cuidado maior em não fazer afirmações contundentes pode ter surgido para dialogar com visões diferentes que são agregadas ao texto de 1999. Incorporam-se argumentos de um artigo de autoria de Geraldo Gomes publicado no ano da escrita do primeiro artigo de Amorim (posterior a ele), em que Gomes coloca que "solidário com o seu tempo e com o espaço geográfico onde exercia a profissão, Amorim era um modernista e, como tal, não escondia a natural e generalizada aversão contemporânea à arquitetura eclética, então pejorativamente chamada de arquitetura do 'bolo confeitado'" 33 . Para esse autor, há a hipótese de justificar-se a intervenção no Luciano Costa "simplesmente como uma prática visando à redução de custos da obra". Para ele, ainda, a "indiferença ao contexto urbano eclético" encontrado no prédio Luciano Costa vai se repetir em diversas outras obras do arquiteto, argumento com que Luiz Amorim concorda apenas em parte, apontando um projeto de 1947, em Póvoa de Varzim, em que houve "diálogo entre as edificações vizinhas".

A ideia da "intencionalidade" do arquiteto em preservar a fachada eclética, a mais fortemente presente no artigo de Amorim de 1994, apareceu na Ficha Cadastral do imóvel (1998) que acompanhou a proposta de tombamento, assim como no parecer da 5 SR, de 1999, mas como argumentos que fragilizam a importância de preservação da fachada de cobogós. É possível que o artigo de 1994 tenha sido consultado pelos técnicos da prefeitura e do Iphan, iá que 
há cópias dele nas pastas do arquivo do Iphan relativas ao processo do edifício Luciano Costa. É possível, também, que Amorim estivesse ciente do uso desse argumento pelos defensores da retirada do cobogó, de forma que, no artigo de 1999, aparece um parágrafo novo, em que o arquiteto relativiza a importância em se saber qual tenha sido a intenção do arquiteto:

É muito difícil especular sobre ideias que, presumivelmente, edifícios podem anunciar. No caso em estudo, o seu autor não está presente para discutir os fundamentos utilizados para o desenvolvimento do projeto, nem tampouco existem documentos que os comprovem. Por outro lado, os edifícios, de fato, nos falam, nos afetam os sentidos, e é a ele [sic] sempre que devemos nos reportar, porque arquitetura é antes de tudo obra edificada. No caso do ediff́cio Luciano Costa, mais importante do que as intenções do arquiteto, são as indagações formuladas, e ainda presentes, quando o arquiteto decidiu pelo envolvimento do edifício eclético. $\bigcirc$ que é interessante discutir agora não é se o edifício é representativo ou não do pensamento do arquiteto. Se ele representa uma antevisão consciente de posturas preservacionistas ou uma atitude revisionista frente aos cânones modernistas, parece ser de pouca importância. $\bigcirc$ edifício não é apenas importante porque é um exemplar inusitado no conjunto da produção do arquiteto. A obra suplanta o seu autor, porque as questões que ele encerra não podem ser limitadas pelos contornos de sua obra ${ }^{34}$.

Em síntese, o arquiteto, apesar de interpretar a obra de Delfim Amorim como reveladora de uma atitude de "preservar" a fachada eclética, entendia que uma possível intervenção no prédio deveria considerá-lo em sua condição atual, que ele classifica como sendo de "hibridismo", valorizando simultaneamente, no edifício, ecletismo e modernismo.

Houve, para discussão do assunto, uma reunião na $5^{a} \mathrm{SR}$, com participação da Fundação do Patrimônio Histórico e Artístico de Pernambuco (Fundarpe), Universidade Federal de Pernambuco (UFPE-Mestrado em Desenvolvimento Urbano) e Prefeitura da Cidade do Recife (PCR), embora não se tenha registro do conteúdo da mesma. Há indícios de não ter havido consenso sobre o caso, já que a 5a SR pede, ainda em 2000, ao Departamento de Documentação (Deprot), no Rio de Janeiro, um parecer sobre o assunto. Em documento de março de 2001, essa falta de consenso é explicitada, quando a superintendente do Iphan envia um Memorando à chefe da Divisão de Estudos de Acautelamento da Deprot-Rio, cobrando o parecer conclusivo desse departamento. Ela informa que o pedido ao Rio de Janeiro teria sido feito em função da não concordância do Departamento de Preservação dos Sítios Históricos da Empresa de Urbanização do Recife (DPSH-URB-Recife), já que este "questiona o parecer desta Regional, em relação aos termos contidos na documentação do tombamento do referido Conjunto" 35 .

Outro indício da falta de consenso nesse caso é o envolvimento do Ministério Público de Pernambuco ${ }^{36}$, que, por sua vez, aciona a Fundarpe para esclarecimentos sobre o caso. É a partir desses documentos de comunicação da Fundarpe com o Ministério Público que se percebem os primeiros posicionamentos daquela instituição, desde já opostos aos do Iphan. Em março de 2001 , a $13^{\text {a }}$ Promotoria de Justiça de Defesa da Cidadania da Capital escuta a Fundação. $\bigcirc$
34. Cf. Luiz Amorim (1999, p. 11).

35. Iphan, $5^{\text {a }}$ SR, Memorando 129, de 28 mar. 2001. Documento assinado por Cremilda Martins de Albuquerque, então superintendente regional.

36. Procedimento de Investigação 13200OPIPO - Danos ao Patrimônio Histórico-Cultural. 
37. MP, Termo de Declaração, 13_TD 006/2001. Rosa Bomfim é a depoente referida na declaração.

38. Ibidem.

39. Fundarpe, Ofício Pres. 102/2001. Documento assinado por Romero Pereira, então presidente da instituição.

40. Iphan, Deprot, Parecer n.34/01, encaminhado pelo Ofício 158/01, de 26 abr. 2001. Documento assinado por Cláudia Girão, então chefe da Divisão de Estudos de Acautelamento do Deprot.
Termo de Declaração trata da atuação da Fundarpe e, também, de diversos bens culturais, dentre eles o edifício Luciano Costa. Sobre ele, dentre outras coisas, está anotado que,

sobre a possibilidade de retirada deste combogó, existem especialistas que defendem a retirada de apenas parte, como defendem a depoente e a Arquiteta Betânia Correia de Araújo; que qualquer intervenção no prédio dependeria de consulta ao Iphan porque o bairro é tombado, podendo a Fundarpe iniciar um procedimento caso acionada, abrindo a discussão juntamente com o Iphan; que, em relação aos prédios modernos situados no bairro do Recife, nenhuma medida de força poderá ser tomada; que, durante muito tempo, a arquitetura moderna não valorizou, principalmente, o estilo eclético ${ }^{37}$.

As depoentes da Fundarpe anotavam seu apoio a uma solução projetual de conciliação entre as duas fachadas, a partir da retirada de apenas parte dos cobogós.

Com a inserção desses novos agentes, estava delineado o campo de disputas. De um lado, o Iphan e os proprietários; de outro, a Prefeitura do Recife, a Fundarpe e os arquitetos defensores da fachada de cobogós.

Dentre as "deliberações" contidas no referido documento do Ministério Público, encontra-se a de solicitar ao Iphan e à Fundarpe um estudo "sobre a possibilidade de determinar a revisão de intervenção arquitetônica no prédio [...] onde foram colocados combogós em toda a sua fachada" 38 .

Em março de 2001, seguindo essa resolução, o Promotor da $13^{a}$ Promotoria envia ao então diretor do Deprot pedido para que o lphan realize o referido estudo.

Em abril de 2001, a superintendente do Iphan recebe ofício da Fundarpe solicitando reabertura das discussões sobre a reforma, para atender ao pedido do Ministério Público ${ }^{39}$. Enquanto ocorre essa movimentação por parte da Fundarpe, o lphan recebe o primeiro parecer do Deprot ${ }^{40}$.

O parecer é um elenco de "considerações básicas" que a autora, uma arquiteta, situa como importantes para a condução do assunto. Ela procura problematizar o conteúdo da Ficha Cadastral que situou o imóvel como de destaque no conjunto. Lança alguns argumentos que fortalecem a ideia da Ficha, de que a intervenção foi "salvadora", e outros que enfraquecem esse argumento. Dentre os primeiros, está o de que o partido arquitetônico da nova fachada foi o de trabalhar "museograficamente" a edificação eclética, já que deixaria transparecer, a certa distância, a primeira fachada. Ao mesmo tempo, aponta que, para sobrepor a fachada de 1960, houve remoção de elementos da fachada da década de 1910, conferindo a ela uma "função estética secundária". Conclui, em relação a esse aspecto, que, como "intervenção salvadora" não se pode dizer que "tenha sido totalmente bem sucedida".

O outro eixo de argumentação, que até o momento não tinha aparecido em outros documentos, é o do conforto. Para a parecerista, "a sensação de se estar dentro do prédio, sobretudo quando se chega à janela, é de desconforto" e "deve ser levado em conta". Essa linha de argumentação se encontra com a anterior, quando ela aponta que o preconizado "bem morar, bem estar" da 
arquitetura modernista não foi alcançado no projeto de Amorim, pelo desconforto causado, "podendo-se aduzir na segunda fachada uma condição temporária, uma intenção de permitir um possível resgate da fachada original". Volta-se mais uma vez ao argumento da "intencionalidade".

Com a questão do conforto, aponta-se a importância de um valor de uso, ancorado no presente, mas, nesse caso, essa valoração é exclusivamente do técnico, em uma experiência sensorial possível quando de sua vistoria no prédio. Em nenhum momento, no parecer, aparece a necessidade de escutarem-se as pessoas que usam o prédio, ou as pessoas do bairro, ou as pessoas da cidade, para identificar que valores elas atribuem ao edifício com sua fachada modernista.

Sem chegar a qualquer posicionamento claramente contra ou a favor da retirada da fachada de cobogós, coloca-se ser importante ter um parecer da Coordenação de Conservação. Vai ser esse o parecer a representar o posicionamento final do Deprot.

Antes de ter a Coordenação de Conservação concluído seu parecer, em julho de 2001, a Fundarpe envia carta à 5a SR, solicitando a participação da mesma nas discussões sobre a reforma da fachada do edifício Luciano Costa. Encaminha, conjuntamente, um convite e uma lista de convidados para um debate $^{41}$ sobre o assunto, solicitando que, junto com a Fundação, o lphan conduza esse evento. No convite, coloca-se como objetivo aquele de "propor uma solução consensual para o tratamento das fachadas do edifício Luciano Costa". Para abertura do debate, convidam o "Professor Luiz Amorim", "para apresentar suas reflexões sobre a obra do arquiteto Delfim Amorim, em especial, da reforma do Luciano Costa", citando o artigo escrito por Amorim em 1994. O convite a Amorim é indício do posicionamento da instituição.

Na visão da Fundarpe, o debate seria destinado a "instituições e profissionais interessados". Além do Iphan e do Departamento de Preservação dos Sítios Históricos da Prefeitura do Recife e do Ministério Público do Estado de Pernambuco, diretamente envolvidos, são listados dois conselhos /Conselho Estadual de Cultura e Conselho Regional de Engenharia, Arquitetura e Agronomia), um museu (Museu da Cidade), uma instituição com presença forte de historiadores (o Instituto Arqueológico, Histórico e Geográfico de Pernambuco), duas instituições de planejamento (Secretaria de Planejamento da Prefeitura e Fidem) e a Fundação de Cultura da Cidade do Recife (Secretaria de Cultura). Da Universidade Federal de Pernambuco, só o Departamento de Arquitetura e Urbanismo e o Mestrado em Desenvolvimento Urbano estão presentes na lista. Os "profissionais" convidados são todos arquitetos.

Não se pode afirmar o motivo, mas, a partir da lista de presença encontrada na Fundarpe ${ }^{42}$, vê-se que não compareceram as instituições que poderiam, em princípio, garantir alguma diversidade de olhar (com planejadores e historiadores), e o debate terminou sendo um debate, sobretudo, institucional e de especialistas - arquitetos. Também houve significativa perda quantitativa em relação à lista de convidados. Dos 21 "profissionais" listados, foram apenas 5.
41. A ideia do debate partiu de Rosa Bomfim, arquiteta da Fundarpe. Em março de 2001, Milton Botler, então diretor do Departamento de Patrimônio Histórico, escreve (atrás de um ofício de autoria de Rosa Bomfim): "solicito organizar uma minuta de programação para um debate sobre o tema, conforme sua proposta (mencionada verbalmente). Favor incluir data e lista de participantes (local tb.)".

42. Participaram: Milton Botler (Fundarpe); Ulisses Pernambucano de Melo (Fundarpe); Betânia Araújo (Fundarpe); Rosa Bomfim (Fundarpe); Neide Fernandes (Fundarpe); Carmem Murano (Fundarpe); Luis Moriel (Fundarpe); Letícia Bandeira de Mello (Iphan); Cremilda Albuquerque (Iphan); William Bernardo (Escritório de Revitalização do Bairro do Recife, ERBR); Isabel Rocha (ERBR); Aida Gusmão (ERBR); Sandra Spinelli (ERBR); José Nilson (DPSH-Departamento de Preservação dos Sítios Históricos-URB Recife); Paula Gonçalves (Porto Digital); Ricardo Coelho (Ministério Público de Pernambuco); Geraldo Magela (Ministério Público de Pernambuco); Antônio Aristóteles Bastos (IAB); Antônio Carlos Maia (Crea); e os arquitetos Moisés Andrade; Mônica Raposo; Fernando Borba; Ronaldo Lamour; e Paula Peixoto. 
43. Institucional: $71 \%$, sendo $58,31 \%$ de órgãos ligados à preservação (Fundarpe: $29,16 \%$, Iphan: $8,33 \%$, ERBR: $16,66 \%$, DPSH: $4,16 \%$ ), e $12,49 \%$ de órgãos não ligados diretamente à preservação (Porto Digital: 4,16\%, Ministério Público: 8,33\%); Sociedade Civil: $29 \%$, sendo $20,83 \%$ de Arquitetos, $4,16 \%$ de representantes do IAB e $4,16 \%$ de representantes do Crea.

44. Rosa Bomfim, Manuscrito, sem título, encontrado no arquivo da Fundarpe. O documento não está assinado, mas a própria Bomfim identificou sua letra e ajudou a "decifrá-la".

45. Fundarpe, DPH, Ofício no $152 / 2001$. Documento assinado por Milton Botler, então diretor do DPH.

46. Ver Cleide Alves (2001)
Os percentuais de participação revelam presença institucional de $71 \%$, sendo $58 \%$ de instituições ligadas à preservação, contra $29 \%$ da sociedade civil, representada unicamente por entidades representantes de arquitetos ou por profissionais liberais do campo da arquitetura ${ }^{43}$.

Foi encontrado um documento que contém algum relato das discussões ocorridas no debate. São as anotações pessoais de uma arquiteta da Fundarpe ${ }^{44}$. As anotações são fragmentárias, com frases curtas, dificultando a análise, mas trazem informações importantes.

Segundo o documento, a mesa foi composta por representantes do Ministério Público de Pernambuco, da Fundarpe, do DPSH e por Luiz Amorim. A ausência do Iphan, chamado no convite a "conduzir" o debate juntamente com a Fundarpe, pode ser indício de algum desconforto institucional. A Superintendente do $5^{\text {a }}$ regional do Iphan estava, inclusive, participando do evento, tendo assinado a lista de presença. A força de Luiz Amorim nesse evento também é bem representativa do posicionamento da Fundarpe.

Pelo manuscrito, apreende-se que as discussões giraram em torno, sobretudo, das formas de conduzir o processo e das possíveis maneiras de intervir no prédio. Há um único registro sugerindo se "abrir a discussão à população, não restringir aos arquitetos". Sobre as possíveis intervenções arquitetônicas, há trechos que levam a entender ter-se discutido a possibilidade de tirar apenas parte dos cobogós. Aparece sugestão de se "levantar o que existe do ecletismo e descobrir alternativas de cobrir e descobrir", apesar da "dificuldade de dosar a nova intervenção" apontada. As questões de salubridade, por sua vez, ganham visibilidade, quando se fala em "ponto de poeira e de doenças". Anota-se, ao final, que "a gente já chegou a uma posição de consenso".

Outro documento da Fundarpe ${ }^{45}$, analisado mais adiante, esclarece que esse "consenso" foi o de "manter, em parte, os anteparos da fachada colocados pelo arquiteto Delfim Amorim, de forma a conviver com a exibição de trechos da fachada original do imóvel". Os presentes não teriam chegado, apenas, à conclusão "do percentual de aproveitamento desta 'membrana' de envolvimento das fachadas do Luciano Costa, a ser definido através de proposta a ser submetida em nova decisão plenária". Se conciliariam, em proposta arquitetônica, os desejos antagônicos de conservar plenamente a fachada de cobogó, por um lado, e de retirá-la completamente, por outro. Em seguida ao debate, em 5 de agosto de 2001 , o Jornal do Commercio divulga matéria sobre a polêmica e sobre o debate ocorrido, com o título: "prédio de combogós é alvo de polêmica"46.

artigo do Jornal do Commercio revela diversos depoimentos, sendo mais uma fonte dos posicionamentos das pessoas envolvidas. $\bigcirc$ promotor aparece na reportagem reforçando a dimensão de conflito presente no caso: "não há um consenso. Uns querem tirar, outros preferem manter e alguns sugerem a preservação das duas fachadas". Luiz Amorim, por sua vez, faz declarações que confirmam seus escritos anteriores, enxergando um pioneirismo preservacionista em Amorim: "Na época, a arquitetura eclética não era valorizada no Brasil e Delfim Amorim teve essa visão de futuro. Ele também antecipa o conceito de harmonia do conjunto 
urbano, pois se um dia os elementos vazados fossem retirados, o imóvel estaria contextualizado com o casario". Para não dar um bom argumento aos adversários, Amorim complementa: "porém, a obra se tornou mais importante que o sujeito que a criou e o que não faz sentido, hoje, é atender à vontade do mestre". Na reportagem, também tiveram voz os proprietários, a Prefeitura (Escritório Técnico do Bairro do Recife), a Fundarpe e o lphan.

Os proprietários mais uma vez deixam transparente sua intenção de se inserir no plano de "revitalização" do Bairro do Recife e usufruir dos possíveis benefícios envolvidos: "Precisaremos de apoio para fazer a restauração, como tiveram os outros proprietários de imóveis no Bairro do Recife". É a partir dessa reportagem que eles ficam sabendo do debate ocorrido e escrevem ao Iphan protestando por não terem sido convidados. Aproveitam para reiterar seus argumentos a favor da retirada dos cobogós. Anexam, dessa vez, uma pesquisa com os inquilinos que revela que 12, de um universo de 13, são a favor da retirada dos cobogós. É a primeira vez que se vê referência a eles durante todo o processo, fortalecendo a legitimidade da demanda dos proprietários ${ }^{47}$.

Na reportagem, Nara Spencer, coordenadora do Escritório de Revitalização do Bairro do Recife, diz que a prefeitura ainda está discutindo o assunto e que a "análise e a decisão final será em conjunto com o lphan". Menos imparcial, Milton Botler, diretor de Patrimônio da Fundarpe, opina que as duas linguagens devem ser preservadas, por contar a história da arquitetura em Pernambuco. Foi a primeira vez que, nas fontes pesquisadas para esse artigo, apareceu a atribuição de um valor de testemunho ao edifício, em prol da sua conservação. $\bigcirc$ diretor ainda destacou a importância do debate: "O debate é um marco, estamos somando esforços". O Iphan, na fala de Cremilda Albuquerque, reafirmou o posicionamento da instituição: "A prefeitura pediu o parecer do Iphan. Por escrito, concordamos com a retirada. Entendemos que aquela intervenção é uma ação preservadora temporária que já cumpriu seu papel. Porém estamos abertos ao debate e respeitamos as opiniões".

Apesar de ter a fala da superintendente apontado para uma abertura ao debate e respeito das opiniões, poucos dias depois, em 15 de agosto de 2001, o diretor do Deprot envia Memorando para a 5a SR, encaminhando o "parecer conclusivo" da instituição, dizendo estar "de pleno acordo" e anotando que "aos interessados resta apresentar o projeto de restauro para exame e aprovação dessa Superintendência"48.

parecer conclusivo do Deprot é de 30 de agosto de 2001, mesmo dia do debate, o que significa que nele não se levou em consideração o conteúdo das discussões tidas.

Já em suas primeiras considerações, o arquiteto autor do parecer deixa explícito o desconforto que a retirada de um acréscimo posterior à época da primeira edificação causaria a entendimentos contemporâneos no campo do restauro, o que o faz qualificar mais adiante a intervenção da "membrana de cobogó" como uma intervenção que não teria sido "incorporada" à arquitetura do prédio, como se fosse "um curativo aplicado sobre alguma coisa que foi considerada em risco e que merecia ser protegida" 49 :
47. Carta de 21 ago. 2001, assinada por Martha Costa de Rooy e Ida Costa Bezerra de Mello (representada por Elza Costa Lopes), endereçada à $5^{\text {a } S R . ~}$

48. Iphan, Deprot, Memorando 264/2001 GAB/Deprot, de 15.8.2001. Documento assinado por Roberto de Hollanda.

49. Iphan, Deprot, Parecer $072 / 2001$, fl. 3. Documento assinado por José Aguilera, arquiteto do Deprot. 
50. Idem, fl. 2.

51. Ibidem.

52. Cf. Lira (2009, p. 93).

53. Idem, p. 99
As correntes de preservação atualmente aceitas internacionalmente, e das quais o Iphan participa, propiciam a preservação dos monumentos respeitando todas as intervenções nele introduzidas, desde que signifiquem uma reinterpretação arquitetônica, como testemunhas documentais da sua passagem através do tempo. A regra é, então, a preservação dos acréscimos sendo que a sua remoção constitui exceção que deve ser justificada. Esta regra deixa de ser aplicada, por exemplo, quando se trata de elementos que por ser [sic] meramente utilitários ou simples modismos, mesmo estando justapostos, não chegam a se incorporar a [sic] arquitetura do prédio $^{50}$.

Para fortalecer a interpretação de que a fachada de cobogós não teria sido incorporada à arquitetura do edifício, ele considera que o projeto de Delfim Amorim não seguiria o paradigmático "a forma segue a função", não tendo sido alcançada uma "concordância" entre esses dois aspectos ao se "simular", na "membrana de combogós", um número de pavimentos não correspondente àquele presente no prédio eclético.

Nesse momento, o arquiteto utiliza o conceito de autenticidade para indicar o perigo de se "propugnar a preservação de um elemento que parece ser o que não é, e não é o que parece ser" ${ }^{\prime \prime}$. Existiria, para o autor do parecer, o entendimento de que a essência verdadeira do edifício estaria no corpo eclético, e a fachada modernista não teria correspondido a essa essência, interferindo, assim, na autenticidade do conjunto. Na argumentação em prol do edifício original, é convidado o par "essência" e "aparência".

No momento da escrita do parecer, algumas cartas internacionais haviam abordado a noção de autenticidade e, na primeira delas, a Carta de Veneza (1964), indiretamente se reconhece uma condição para a sua manutenção, quando se afirma que "as contribuições válidas de todas as épocas para a edificação do monumento devem ser respeitadas, visto que a unidade de estilo não é a finalidade a alcançar no curso de uma restauração". Para Lira, a partir daí, a autenticidade passa a ser inerente não apenas a um objeto original, mas a todo o palimpsesto histórico de cada processo de desenvolvimento temporal ${ }^{52}$.

Depois da Carta de Veneza, o documento mais importante sobre autenticidade é aquele produzido a partir da conferência de Nara (1994). Esse documento impulsionou alguns países ou grupos de países a elaborarem as suas próprias cartas, tendo o Brasil participado daquela do Cone Sul, a Carta de Brasília, de 1995. Nessa carta, afirma-se que "a mensagem original do bem deve ser conservada [...], assim como a interação entre o bem e suas novas e diferentes circunstâncias culturais que deram lugar a outras mensagens diferentes, porém tão ricas como a primeira". Contudo, também se afirma, mais adiante e contraditoriamente, que a "graduação da autenticidade de um bem" deve ser aferida em função das ideias que deram origem ao bem ${ }^{53}$.

A contradição da Carta de Brasília e o parecer conclusivo do Deprot sobre o Luciano Costa parecem ser indícios da difícil apreensão do conceito de autenticidade.

As conclusões desse parecer são que a intervenção modernista "manteve sempre um caráter de elemento provisório" e que sua remoção é 
justificável, mesmo que, segundo o próprio parecerista, a intervenção "tenha se mantido nessa condição durante mais de quarenta anos", quase metade da idade do edifício.

Ciente desse parecer, em dezembro de 2001, o diretor do DPH da Fundarpe envia para a 5a SR uma carta registrando seu desacordo em relação aos argumentos do Deprot:

"Discordamos do [...] Deprot/Iphan, quando diz que a intervenção de Amorim não se incorporou ao prédio. A nova feição de cunho modernista foi incorporada ao imóvel de forma permanente, com tal arte que se torna impossível a torna-viagem vislumbrada pelo arquiteto, no seu parecer. Isto porque estas inclusões não foram apenas ajustadas ou superpostas aos ambientes e fachadas do edifício, mas, passaram a fazer parte da estrutura de um conjunto que pode ser chamado de híbrido, onde convivem em certa harmonia e entrelaçamento, o eclético e o moderno. O prédio, pois, conta toda a trajetória da prática e do pensamento urbanístico e arquitetônico que modelaram um determinado período da história da cidade." 54

diretor do DPH, como já tinha feito na reportagem do Jornal do Commercio, mostra que, no seu entendimento, a intervenção de Amorim incorporada ao edifício é testemunho histórico, que deve ser preservado pelo seu valor documental.

Ele lembra, em seu ofício, o debate que houve no Teatro Arraial e as conclusões a que os participantes chegaram nesse evento, e sugere que o Iphan encaminhe solicitação ao parecerista, para que retorne ao Recife, "quando tomaria conhecimento do trabalho do Arquiteto Luiz Amorim e da posição dos participantes do debate sobre o Luciano Costa, em especial a da Fundarpe, para se for o caso, encontrar em conjunto a forma ideal de exibição do processo de desenvolvimento (e de certa forma de desconstrução) deste importante imóvel do Bairro do Recife" 55 .

Tendo recebido esse ofício ainda em dezembro de 2001, a superintendente da 5 SR encaminha, para o diretor do Deprot, um Memorando contendo em anexo o ofício da Fundarpe e pedindo, mais uma vez, para que o Deprot tome uma "posição final e definitiva sobre o assunto", responsabilidade que o Deprot devolve, em janeiro de 2002, respondendo que a posição final do Deprot e do Iphan é o que está posto no relatório enviado ${ }^{56}$.

É em abril de 2002, já com outro superintendente, que a 5a SR encaminha para uma das proprietárias a cópia do parecer técnico elaborado pelo Deprot, noticiando ter sido encaminhado também para o Ministério Público de Pernambuco, para subsidiar os procedimentos legais ${ }^{57}$. Estava dado o aval do Iphan para a retirada dos cobogós.

A fachada de cobogós, contudo, ainda permaneceu alguns anos no Bairro do Recife. Numa reviravolta inesperada dessa história de quase 3 anos, os proprietários mudaram seu posicionamento. A neta da proprietária do segundo pavimento, arquiteta, que assumiu os negócios da sua família quando seu pai faleceu e entrou em contato com as questões referentes ao prédio em 2002,
54. Fundarpe, DPH, Ofício no 152/2001, fl. 2. Documento assinado por Milton Botler, então diretor do $\mathrm{DPH}$.

55. Ibidem.

56. Iphan, $5^{\text {a }}$ SR, Memorando 651/2001, de $26 \mathrm{dez}$. 2001 , de autoria da superintendente Cremilda Albuquerque, com resposta manuscrita de Roberto Cavalcanti, então diretor do Deprot.

57. Iphan, $5^{\text {a }} \mathrm{SR}$, Ofício 144/2002, de 17 abr. 2002. Documento assinado por Múcio Aguiar Neto, então superintendente regional. 
58. Iphan, $5^{\mathrm{a}} \mathrm{SR}$, Ofício 425/2004, de 24 ago. 2004 Documento assinado por Frederico Almeida, então superintendente regional.

59. Entrevista, concedida a Renata Cabral, em 16 jul. 2009 (gravada).

60. Iphan, $5^{\text {a }}$ SR, Ofício 325/2003, de 12 ago. 2003. Documento assinado por Frederico Almeida, então superintendente regional.

61. Cf. Iphan, $5^{\text {a }}$ SR, Informação 17/CMA/2004, de 13 ago. 2004. Documento que traça histórico da polêmica, assinado por Cremilda Martins de Albuquerque. convenceu os demais proprietários do prédio, seus parentes, a não retirar a fachada de cobogós.

Ofício da 5ํㅗ SR informa que, em reunião com ela, em novembro de 2003, a mesma tinha declarado que os herdeiros não tinham mais intenção de remover o véu de cobogós, "uma vez que é esse elemento que dá visibilidade e distingue o imóvel dos demais" 58 .

A movimentação dos arquitetos em prol da fachada e as notícias no jornal podem ter ajudado os parentes da arquiteta a perceberem a visibilidade pública que o prédio tinha alcançado e as consequências positivas que a manutenção da fachada de cobogós poderia trazer na valorização comercial do prédio, da mesma forma como perceberam, anteriormente, a visibilidade alcançada pelos edifícios transformados pela "revitalização".

Em entrevista concedida em 2009, a arquiteta argumenta que o parecer final do Deprot, ao vincular a autorização para a demolição da fachada de cobogós a um projeto de restauro e comprovação de disponibilidade financeira para a obra, inviabilizou a retirada dos cobogós ${ }^{59}$.

Outros trechos da entrevista levam a entender que as motivações não foram apenas pragmáticas e geradas por uma atribuição de valor de troca comercial ao objeto, mas também por uma atribuição de valor documental, embora não se possa afirmar que a narrativa da entrevista, de 2009, fosse a mesma de 2002. Criticando o parecer do Deprot, a proprietária diz:

Acho que não compete à gente, enquanto arquitetos, dizer o que é feio ou é bonito, enquanto restaurador, cuidador do patrimônio histórico, na minha opinião, não interessa o que você acha [...] então eu poderia até achar que o eclético que tinha atrás era muito mais bonito do que o cobogó que tinha na frente - que o moderno que tinha na frente, mas não compete a mim decidir, porque para mim é bonito, pra você é feio, pra outro é bonito, pra outro é feio, então não importa a opinião pessoal de cada um. Eu acho que qualquer arquitetura, em todo momento, deve ser preservada, tem seu valor, independente de ser mais antiga ou mais moderna, todas têm seu valor.

No início de 2003, os proprietários apresentaram nova proposta de intervenção (introdução de um mezanino no $2^{\circ}$ andar), sem referência a modificações na fachada. Ela foi analisada pelo Grupo Técnico de Trabalho formado, em fins de 2002, por técnicos da Fundarpe, DPSH-URB-Recife, 1ㅁ Regional da Dircon, Escritório de Revitalização do Bairro do Recife (ERBR) e 5a SR -, que considerou não ser apropriado conceder autorização para reformas internas enquanto não fossem resolvidas as questões das fachadas - retirada ou manutenção dos cobogós -, "uma vez que, os proprietários sempre alegaram falta de recursos para a execução dessas obras"60. A obra foi sendo executada, antes do pronunciamento do Iphan.

Em 8 de março de 2004, a arquiteta proprietária apresentou outra proposta, desta vez para ocupação e uso do pavimento de cobertura, com acréscimo de área. Foram apresentadas três ocupações possíveis, todas elas mantendo os cobogós ${ }^{61}$. 
Em 12 de abril de 2004, ocorre reunião do grupo técnico para análise conjunta de processos e o caso do pavimento de cobertura do edifício Luciano Costa entra em pauta. A análise do projeto recai na polêmica sobre a fachada, pois uma arquiteta do Iphan opina que o novo pavimento é "condizente com o edifício moderno e não com o eclético"62. Uma funcionária da Fundarpe diz que "se o edifício moderno vai permanecer, não vê inconveniência na coberta e ocupação do último pavimento"63. Como anotado na própria ata, "chegou-se a um impasse".

Nesse "impasse", tendo os proprietários optado por conservar a fachada de cobogó, restava mesmo às instituições de preservação lutar por uma coberta mais adequada ao edifício eclético ou ao moderno. E aqui, então, os posicionamentos se mantêm os mesmos: o lphan resguardando o primeiro; e a Fundarpe, o segundo.

Indícios de que o que se estava discutindo ao se debater a coberta era, sobretudo, a fachada, encontram-se em parecer interno da 5ª SR:

A adoção de qualquer uma das três opções de ocupação do pavimento de cobertura, inviabilizará definitivamente uma futura remoção dos cobogós, na medida [em] que elimina a cobertura eclética e deixa aparente uma intervenção contemporânea, mais compatível com o modernismo das fachadas de cobogós sedimentando uma solução que se contrapõe ao posicionamento conceitual do Iphan sobre este edifício ${ }^{64}$

$\bigcirc$ compromisso dos proprietários era o de conseguir, com o aproveitamento comercial do pavimento da coberta, verba para restaurar a fachada de cobogós. $\bigcirc$ projeto não foi aprovado.

Nesse documento, encontra-se, ainda, a informação de que a proprietária arquiteta estaria contando, para o projeto da cobertura, com a participação do arquiteto Luiz Amorim.

Em entrevista concedida em 2009, ela fala de suas parcerias com Amorim, sobretudo em relação à fachada. $\bigcirc$ empenho dos dois arquitetos levou a serem feitos ensaios in loco, de uma das ideias:

Ele [Luiz Amorim] até sugeriu uma ideia que eu achei fantástica, que era iluminar: entre as duas fachadas a gente criar, colocar iluminação, para que, durante o dia, o prédio fosse moderno e, à noite, ele fosse eclético, porque quando você acendesse os holofotes então aquilo iria iluminar o que tinha dentro e a gente ia ver através do véu de cobogós. A gente aí fez até um teste [...] alugou uns holofotes grandes, colocou na fachada, ligou, chamou o pessoal do Iphan pra ir e tudo, tarará tarará: não apareceram, não pisaram láb5.

Em novembro de 2005, em um final de semana, um pedaço da laje de coberta desabou ${ }^{66}$. $O$ prédio foi interditado e uma empresa de engenharia foi contratada para fazer um laudo em que se anotou, também, o grave estado de conservação da fachada de cobogós ${ }^{67}$. Os proprietários, nesse momento, resolvem pela retirada dessa fachada.

Em 20 de novembro de 2006, em resposta a ofício da Secretaria de Cultura $^{68}$, sobre autorização para demolição das vigas e pilares em concreto
62. Cremilda Martins de Albuquerque, então arquiteta da $5^{\text {a }}$ SR. Cf. Ata de reunião da comissão técnica para análise conjunta de processos, realizada na $5^{\text {a }}$ regional do Iphan, em 12 abr. 2004, em Recife.

63. Rosa Bomfim. Cf. a Ata da nota anterior.

64. Iphan, $5^{\text {a }}$ SR, Informação n.19/CMA/2004, de 19 ago. 2004. Documento assinado por Cremilda Martins de Albuquerque, então arquiteta da $5^{\text {a }}$ SR.

65. Entrevista concedida a Renata Cabral, em 16 jul. 2009 (gravada).

66. Cf. Coordenadoria de Defesa Civil de Recife, Parecer Técnico Preliminar, 28 out. 2005.

67. Laudo da empresa Engest, de 29 nov. 2005, assinado por Gamal Asfura e Wilson Reinaldo Brasil.

68. Prefeitura da Cidade do Recife, Ofício 63/2006/ DPPC/Secult/PCR 
69. Iphan, $5^{\text {a }}$ SR, Informação $022 / C M A / 2006$, de 20 nov. 2006. Documento assinado por Cremilda Martins de Albuquerque, então arquiteta da $5^{\text {a }}$ SR.

70. Iphan, $5^{\mathrm{a}} \mathrm{SR}$, Ofício 970/2006, de 22 nov. 2006. Documento assinado por Frederico Almeida. armado, reafirma-se o posicionamento inicial do Iphan: "Como já é sabido por todos nós, a demolição destas estruturas em concreto que suportam panos de cobogós, revestindo o prédio original do Luciano Costa, vem inserir o mesmo no contexło urbano do bairro, notadamente eclético"69.

Em 22 de novembro de 2006, o então superintendente da 5a SR aprovou os serviços de "demolição das vigas e pilares em concreto armado, externos à fachada da referida edificação"70, que se iniciaram nesse mesmo ano (Figura 5). Hoje, uma pequena faixa de cobogós permanece no local, mas apenas devido à dificuldade operacional de retirada, gerada pela proximidade de fios elétricos (Figura 6).

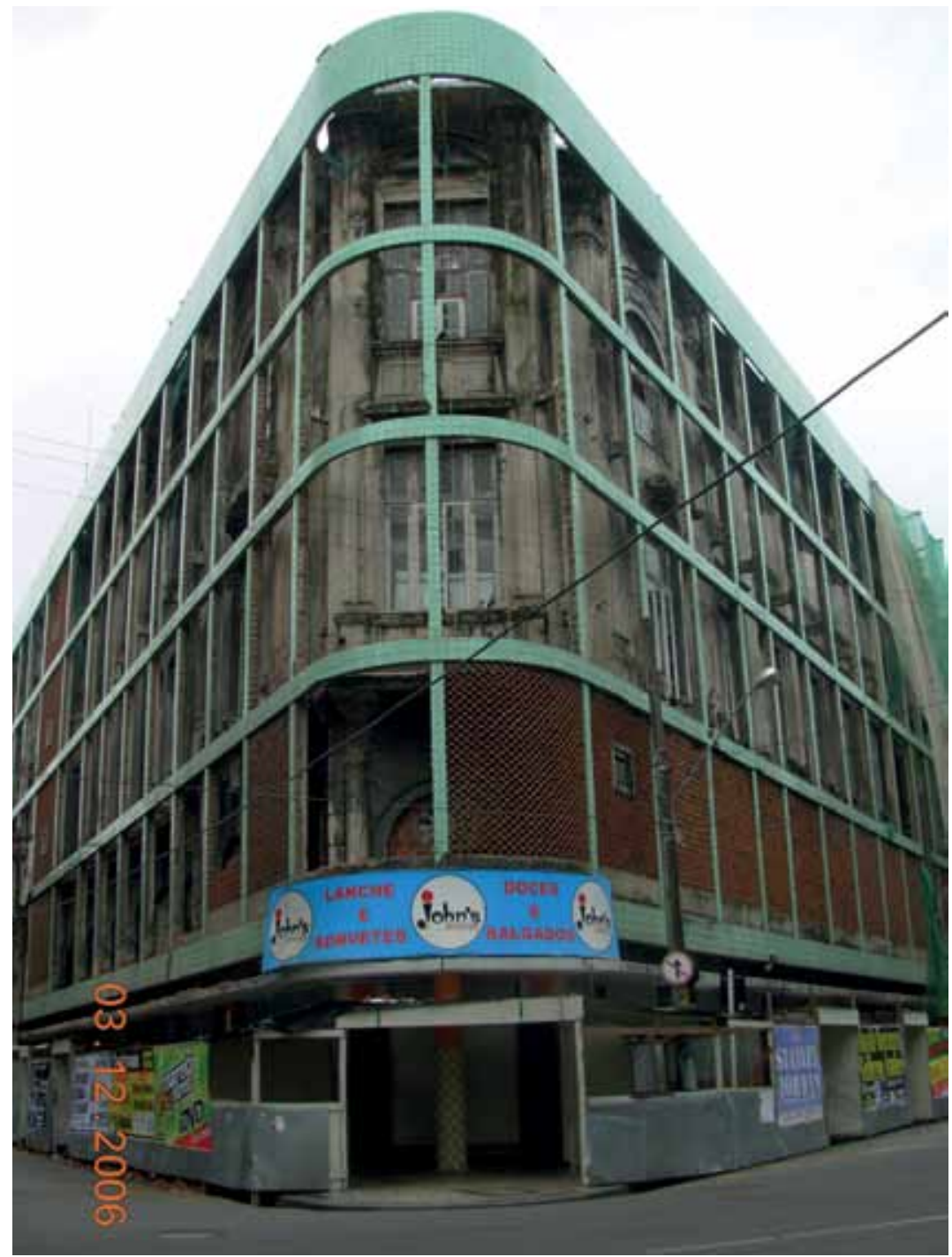

Figura 5 - Edifício Luciano Costa durante o processo de retirada dos cobogós, em 2006. Fotografia de Fátima Campello. Acervo da autora. 


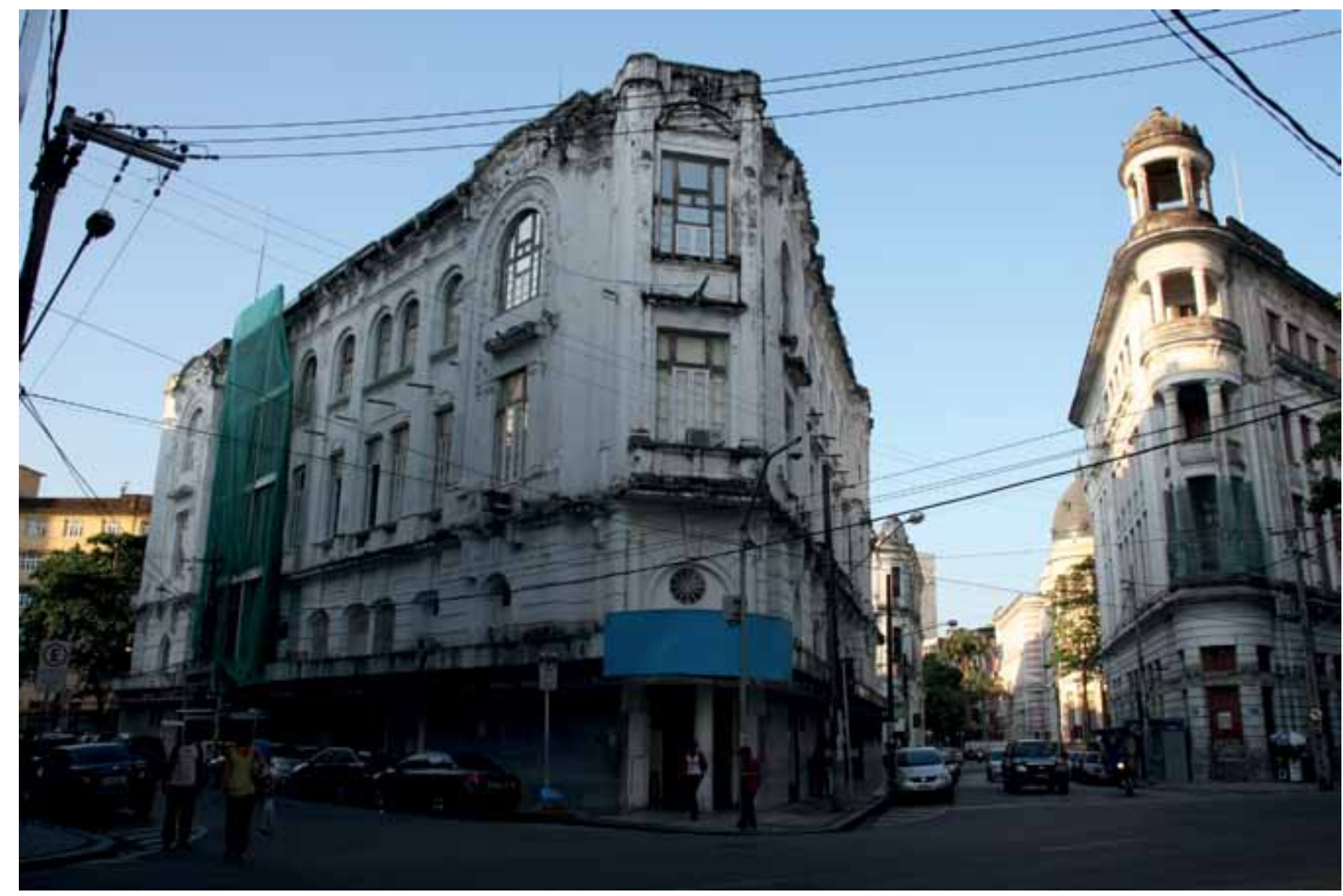

Figura 6 - Edifício Luciano Costa em 2010. Fotografia de Renata Cabral. Acervo da autora.

Esta história finaliza com um casamento, entre o lphan e o ecletismo, que demorou a acontecer e hoje se mostra como uma realidade a ser analisada e compreendida. No caso aqui descrito, essa aproximação ocorreu a partir de alguns critérios:

- Harmonizar e homogeneizar estilisticamente o conjunto urbano onde se insere o edifício Luciano Costa, o que significa devolver ao bem a sua face eclética, valorizando-o junto ao plano de "revitalização" então em curso.

- Interpretar o nível de autenticidade do edifício a partir do que ele foi originalmente, e não a partir da forma como ele se encontrava no presente; e, na avaliação dessa autenticidade, não considerar a construção de significações culturais por parte dos grupos sociais.

- Valorar negativamente a intervenção de Delfim Amorim, pelo não cumprimento a certos paradigmas da Arquitetura Moderna, como "a forma segue a função", sem lançar um olhar historicizado sobre a questão, que revelaria como a obra naquele momento respeitava a 
visão (corrente na cultura arquitetônica modernista) de que a fachada eclética não tinha valor.

- Desconsiderar os valores atribuídos ao bem por agentes envolvidos na polêmica, entendendo que o objeto é detentor de um valor intrínseco, a ser revelado exclusivamente pelos técnicos.

os protestos.

Enfim, o lphan "retirou" o véu da noiva e disse "sim", apesar de todos

Mais do que criticar as ações do Iphan, este artigo procura trazer, com o caso descrito, indícios da necessidade premente de enfrentar-se o desafio de democratizar as decisões relativas ao patrimônio e refletir acerca dos critérios de valoração vigentes na prática do órgão.

\section{REFERÊNCIAS}

FONTES

[ARQUITETA HERDEIRA]. Entrevista, concedida a Renata Cabral. 16 jul. 2009 (gravada).

[BOMFIM, Rosa], Manuscrito, arquivo da Fundarpe.

COORDENADORIA DE DEFESA CIVIL DE RECIFE, Parecer Técnico Preliminar. 28 out. 2005.

ENGEST. Laudo. 29 nov. 2005. Assinado por Gamal Asfura e Wilson Reinaldo Brasil.

FUNDARPE. Ofício Pres. 102/2001. Assinado por Romero Pereira.

FUNDARPE; DPH, Ofício $n^{\mathrm{a}}$ 152/2001. Assinado por Milton Botler.

GOVERNO (Municipal) [Escritório Técnico do Bairro do Recife; Prefeitura da Cidade do Recife] Proposta de Tombamento do Núcleo Original da Cidade do Recife, Ficha Cadastral: Imóveis Destaque ID-14.

[Prefeitura da Cidade do Recife]. Ofício 63/2006/DPPC/Secult/PCR.

IPHAN, $5^{\text {a }}$ SR. Ata de reunião da comissão técnica para análise conjunta de processos, Recife, 12 abr. 2004.

Informação 22/SK/99, 16 set. 1999. Documento assinado por Silvia Katz.

Informação 17/CMA/2004, 13 ago. 2004. Documento assinado por Cremilda Martins de Albuquerque.

Informação 19/CMA/2004, 19 ago. 2004. Documento assinado por Cremilda Martins de Albuquerque.

Informação 022/CMA/2006, 20 nov. 2006. Documento assinado por Cremilda Martins de Albuquerque.

Memorando 129, 28 mar. 2001. Documento assinado por Cremilda Martins de Albuquerque. 
Memorando 651/2001, 26 dez. 2001, de autoria da superintendente Cremilda Albuquerque, com resposta manuscrita de Roberto Cavalcanti, então diretor do Deprot. Hollanda.

Ofício 260/99, 5ª SR/Iphan/MinC, 23 set. 1999. Documento assinado por Roberto de Ofício 144/2002, 17 abr. 2002. Documento assinado por Múcio Aguiar Neto. Ofício 325/2003, 12 ago. 2003. Documento assinado por Frederico Almeida. Ofício 425/2004, 24 ago. 2004. Documento assinado por Frederico Almeida. Ofício 970/2006, 22 nov. 2006. Documento assinado por Frederico Almeida. Portaria n. 263, 23 jul. 1998, publicada no Diário Oficial da União em 24 jul. 1998.

IPHAN; DEPROT. Memorando 264/2001 GAB/Deprot, 15.8.2001. Documento assinado por Roberto de Hollanda.

; __. Parecer 34/01, encaminhado pelo Ofício 158/01, 26 abr. 2001. Documento assinado por Cláudia Girão. Parecer 072/2001. Documento assinado por José Aguilera.

MINISTÉRIO PÚBLICO. Termo de Declaração, 13_TD 006/2001.

Procedimento de Investigação 132000PIPO - Danos ao Patrimônio Histórico-Cultural.

ROOY, Marta Costa de; MELLO, Ida Costa Bezerra de. Carta à 5ª SR, 21 ago. 2001.

; COSTA, Eduardo de Oliveira. Carta de à Diretoria de Programas Especiais (DPE) da Empresa de Urbanização do Recife (URB-Recife), 4 ago. 1999.

URB-Recife. Ofício 479, 13 set. 1999. Documento assinado por Rúbia Campêlo de Farias.

\section{LIVROS E OUTROS}

ALVES, Cleide. Bairro do Recife, prédio de combogós é alvo de polêmica. Jornal do Commercio, Recife, 5 ago. 2001. Disponivel em: <http://www2.uol.com.br/JC/_2001/0508/cd0508_3.htm>. Acesso em: 20 jul. 2009.

AMORIM, Luiz. Edf. Luciano Costa, o Locus da Ruptura ou Alien, o Monstro da Pós-Modernidade. Revista Arte e Comunicação, Recife, v. 1, p. 207-231, jun. 1994.

Edifício Luciano Costa: um enfoque apositivo. In: SEMINÁRIO DOCOMOMO BRASIL, 3., 1999, São Paulo. Disponível em: <http://www.docomomo.org.br/lcosta_sitefinal.doc>. Acesso em: 20 jul. 2009. 2007.

Obituário arquitetônico, Pernambuco modernista. Recife: Instituto Delfim Amorim,

BRUAND, Yves. Arquitetura Contemporânea no Brasil. Trad. Ana M. Goldberger. 3. ed. São Paulo: Perspectiva, 1999. 
CAVALCANTI, Lauro. Modernistas na repartição. Rio de Janeiro: Editora UFRJ; MinC-Iphan, 2000.

FONSECA, Maria Cecília Londres. O patrimônio em processo: trajetória da política federal de preservação no Brasil. Rio de Janeiro: Editora UFRJ; MinC-Iphan, 1997.

GODIM, Djanira Oiticica et al. Delfim Amorim arquiteto. 2. ed. Recife: IAB-PE, 1991.

GOMES, Geraldo. Delfim Amorim. Arquitetura \& Urbanismo, São Paulo, p. 71-79, dez.-jan. 1994-1995.

GOODWIN, Philip L. Brazil Builds. Architecture New and Old 1652-1942. New York: MoMA, 1943.

LEITE, Rogério Proença. Contra-usos da cidade. Lugares e espaço público na experiência urbana contemporânea. 2. ed. Campinas: Editora Unicamp, 2007.

LIRA, Flaviana Barreto. Patrimônio cultural e autenticidade: montagem de um sistema de indicadores para o monitoramento. Tese de Doutorado (Programa de Pós-Graduação em Desenvolvimento Urbano), Universidade Federal de Pernambuco, Recife, 2009.

MARTINS, Carlos Alberto Ferreira. "Hay algo de irracional...". Block, Buenos Aires, n. 4, p. 8-22, dic. 1999.

MICELI, Sérgio. Sphan: refrigério da cultura oficial. Revista do Patrimônio Histórico e Artístico Nacional, Rio de Janeiro, n. 22, p. 44-47, 1987.

MINDLIN, Henrique E. Arquitetura Moderna no Brasil. Trad. Paulo Pedreira. $2^{\text {a }}$ ed. Rio de Janeiro: Aeroplano; Iphan, 2000.

MOTTA, Lia. A Sphan em Ouro Preto: uma história de conceitos e critérios. Revista do Patrimônio Histórico e Artístico Nacional, Rio de Janeiro, n. 22, p. 108-122, 1987.

NOGUEIRA, Ana. O florescer do Bairro do Recife. Diário de Pernambuco, Recife, 22 mar. 1998. Caderno Vida Urbana, p. 52. Disponível em: <http://www.dpnet.com.br/anteriores/1998/03/22/ urbana8_0.html>. Acesso em: 20 out. 2010.

PESSÔA, José (Org.). Lucio Costa: Documentos de Trabalbo. Rio de Janeiro: Iphan, 1999.

Brasília e o tombamento de uma ideia. SEMINÁRIO DOCOMOMO BRASIL, 5., 2003, São Carlos. Disponível em: <http://www.docomomo.org.br/seminario\%205\%20pdfs/074R.pdf>. Acesso em: 20 jul. 2009.

PREFEITURA DA CIDADE DO RECIFE. Proposta de tombamento do núcleo original da cidade do Recife ('Dentro de Portas'), 2. Detalhamento da proposta técnica. Recife: Empresa de Urbanização, 1998.

RUBINO, Silvana. O mapa do Brasil passado. Revista do Patrimônio Histórico e Artístico Nacional, Rio de Janeiro, n. 24, p. 97-105, 1996.

Artigo apresentado em 3/2010. Aprovado em 9/2010. 